\title{
Linguocultural and Cross-Cultural Components in the Structure of the Word
}

\author{
Galina Vasilievna Klimenko \\ Department for the Teaching of Foreign Students, Moscow State Linguistic University, Moscow, Russia
}

Email address:

gal.klim2009@yandex.ru

To cite this article:

Galina Vasilievna Klimenko. Linguocultural and Cross-Cultural Components in the Structure of the Word. International Journal of Language and Linguistics. Vol. 6, No. 1, 2018, pp. 20-23. doi: 10.11648/j.ij11.20180601.14

Received: January 17, 2018; Accepted: January 31, 2018; Published: March 6, 2018

\begin{abstract}
The article introduces a new approach in linguoculturology based on the semantic analysis of the lexemes, which may become perspective in the studies of the triad: language - personality - national world view. The paper manifests the relevance of this approach, determines the aim - the research of the semantic structure of a lexeme, and the object - common neutral vocabulary ("face, hand, head, metro, dacha, bath-hous, cottedge"). The analysis of the word's meaning sheds light on the differences between linguocultural and cross-cultural components of words. A set of methods are used: the method of the analysis of the vocabulary definitions, the contextual method and the component analysis of lexemes. The anticipated results provide an opportunity to understand and explain the world view in multisystem languages. This research has both theoretical and practical value.
\end{abstract}

Keywords: Linguocultural Components, Cross-Cultural Components, Semantic Structure

\section{Introduction}

At present the teaching of foreign language is based on the theory of cross-cultural communication. It has been not long ago that the discipline of Intercultural Communication has appeared on the curriculum of study courses at the universities of all the world.Now communication studies is going to be one of the leading disciplines of the 21-st century. There are intercultural issues in the economy, medicine, business, politics and especially in the teaching of languages.

The model of understanding of the foreign culture is a cognitive model of the real world. It goes through perception of new notions, decoding their meanings and contents to the conceptualization and interpretation.It is important to add new knowledge to the well-known ones.

The problem of adequacy of the communication in the cross-cultural domain is solved with the help of linguocultural and regional geography studies. Both disciplines pursue one aim: a dialogue with "foreign minds". Linguistic regional geography has for a long time played an important role in foreign language teaching whereas linguocultural study has recently become an actual branch in the methodology. The lack with the traditional view is in the fact that identifies only one type of components - extralinguistic, linguistic regional geography, etnolinguistic.

The object of linguocultural study is language and culture in their interaction as a type of consciousness. The study of culture such as reflection in national languages and interpretation of language factors through the cultural component becomes an extremely perspective for the fundamental science and for the language teaching methodology.

\section{Theoretical Framework}

The analysis of terms in the interdisciplinary space shows their abundance, their polysemy and often a dubbing character. Thus considering the current terms of culturology (polyonim, idyoculturonim, xenonim, culturonim) we come to the conclusion that their content correlates with the linguistic terms. Polyonims reflect cross-language lexical concepts - the so-called equivalent lexis and idyoculturonims are culture specific lexical items with no equivalents in other languages. The terms of linguocultural study in their turn logoepistem, linguoculturem etc. - are too voluminous which made us choose more concrete definitions.

The article uses the term "cross-cultural components" introduced by Vereschyagin E.M. and Kostomarov V.G. [3], 
i.e. the words with incomplete equivalence containing crosslanguage concepts and specific non-conceptual content. For example, the word "аптека" (pharmacy) in Russia denotes an institution where medicine is sold whereas in the USA it is an institution where not only medicine but also a chewing gum, products and beverages can be bought. Another example is the word "кафе" (café): in Russia one can have breakfast, lunch, dinner or have a cup of tea, coffee and an alcohol drink in a café; in Poland one can't have lunch but can only have a cup of coffee, a glass of wine etc. and have a cake in a café.

Besides the term "linguocultural component" is used to denote the part of a language sign which reflects the nationality specific perception of reality, and as a consequence, the cultural element of this or that language society. This component differs from the cross-cultural parts which bear extralinguistic character. The examples of such words will be brought up further.

The article brings a hypothesis that common words contain in their structure cross-cultural components directly connected with the extralinguistic reality (аптека, кафе, дача, баня еtc.) and linguocultural components revealing the specific national world view (воля, удаль, тоска). To the second group such seemingly ordinary words as "голова" (а head), "лици" (a face), "рука" (a hand), "нога" (a leg) are referred.

\section{Method}

The methotodological base of this research represented by: 1) linguoculturological approach to the problem of the world view; 2) the concept of the meaning of the word as a phenomenon which reflects a certain linguocultural society's experience. A set of methods are used: the method of the analysis of the vocabulary definitions, the contextual method and the component analysis of lexemes.

\subsection{Data Analysis of Words with Cross-Cultural Components}

Let's have a closer look at the first group of words and demonstrate that their structures contain cross-cultural components, i.e. components closely connected with extralinguistic reality, in our case - Russian.

The word "коттедж" (cottage) is an English borrowing where it denotes "a small village house", "a small summer house at a resort, in a village". But for the Russian native speaker this word is associated with a two- or three-storey comfortable house outside the city for all-season usage and built by "New Russians". "Баня" (a bath house) for the Russian mentality is not only a place where people can have a bath, but also where people have a rest, tea, beer etc. The word "дача" (a summer house) has the following cultural parts: "6 соток" (6 hundredth of a hectar), "огород" (а garden), “летний отдых на природе" (summer rest in the fresh air) and even "шашлык" (barbeque). Nowadays it is preferable not to translate this word as "a summer cottage", but to use a direct borrowing from the Russian language "dacha". These lexemes can be referred to the incomplete equivalent words and consequently to the branch of regional geography. Such a word as "мempo" (underground, subway) also refers to this type. This word well known to the citizens of a metropolis is defined as “городская подземная электрическая железная дорога, иногда проходящая по эстакаде, над землей" (a city underground electrical railway sometimes going along the trestle above the ground). In the current Russian language this lexeme has a cross-cultural component as native speakers' perception of "metro" is not only restricted by a means of transport, but also a place for meeting inside or near the station, a place for shopping and entertaining centres near the underground. The Moscow underground recovers the images of "underground palaces" as many stations in Moscow refer to the architectural masterpieces which have sculptures and fundamental painting. They are officially declared by UNESCO as cultural objects of world significance.

In their turn the words "хрущёвка" (from the last name of the soviet leader of the $60^{-\mathrm{s}}$ in the XX century N.S. Khrushchev), “коммуналка" (shared apartment), “спальный район" (a district on the outskirts of a city) raise quite different emotions. These words may be definitely referred to the culture specific lexis with no equivalents as their semantization requires a detailed comment based on regional culture knowledge.

\subsection{Data Analysis of Words with Linguocultural Components}

Further the words with cultural specific components will be analyzed. In our opinion such words are the words that denote the upper and lower limbs of a human body, in particular the lexemes "рука" (a hand) and "нога" (a leg). All the explanatory dictionaries give the following definitions: a hand- a) one of the upper limbs of a human body from the shoulder to the finger tips; б) the one who is able to give help, protection; в) power, patronage. A leg - a) one of the two lower limbs of a human; б) Bearing, lower end (of furniture, mechanisms).

In other languages, for example, English and French, a different phenomenon is noted where these parts of the body are divided which consequently leads to a more number of lexemes: an arm (Eng) - a limb from the shoulder to the wrist; a hand (Eng) - a wrist; le bra (Fr.) - a limb from the shoulder to the wrist; la main (Fr.) - a wrist; a leg (Eng) - a limb from the hip to foot; a foot - foot; la jambe (Fr.) - a limb from the foot till knee; le pied - foot.

The given differences demonstrate the specific world view even in the direct meanings of the word. Analyzing the transferred meanings we may reveal a series of differences connected with the sociocultural moments. Thus, for example, only in the Russian language the word "рука" (a hand) may denote the whole individual: In May 1933 Inner Minister, the right hand of F. Roosevelt, indomitable Harold Ickes reported the President about "demoralization" of the oil industry [(gaz.Zavtra, 2003, 08. 22);]; One had to postpone the non-urgent operations because of lack of hands 
[6]. Comparing the Russian word "рука" (a hand) and the English words arm, hand, it can be seen that only the lexeme hand may be used to denote a person, in particular - a person of labour, a worker: a person who engages in manual labour, especially in a factory, on a farm, on board a ship [10]. The English synonyms dictionary introduces only the synonyms of the lexeme "hand": operative (a mechanik), workman (a labour man), workingman (a labour man), laborer (a labour man), craftsman (a labour man), handicraftsman (a work man), mechanic (a mechanik, operator), artisan (a craftsman), roustabout (a labour man), worker (a labour man) [11].

One of the transferred meaning of the word "рука" (а hand) is also worth noting -"power, patronage given to someone", for example: An offended person has no right to despond as one knows that there is a hand which protects them and punish the villain [5]; Moscow hands disembark on the $30^{\text {th }}$ of April 2002 landing of Moscow investing group "Aton" (the newspaper "Sovershenno sekretno", 2003, 09.01); The director Balabanov's hand is quite evident in the film (the newspaper "Kultura", 2002, 03.25). This meaning may be considered very specific to the Russian linguistic view of the world.

\subsection{Procedure}

Let's consider some other examples of common words. Thus the lexeme "голова" (a head) has similar semantic structure in different languages: the direct meaning (upper part of a human's body) and transferred (mind, reason; director, chief; the front part of a group or column, etc.) coincide in the Russian, English and French languages: good head for mathematics, head of school, tete de colonne. There are even similar proverbs and sayings in Russian and English languages: $У_{м}$ хорошо, а два лучше; Two heads are better, than one. But this doesn't refer to such an important nomination as "лицо" (face). The word "лицо" (a face) has the following analogues in all European languages: a face, le visage. The lexeme in the Russian language is full of nationality based cultural components. It may refer not only to the part but a whole individual: " $В$ зале появилось новое лицо" (A new person appeared in the hall). "В храме, между прочим, находилось одно приезжее лицо, оно прибыло сюда по делам" (There was a new visitor in the church, who arrived for business here) (M. Zoschenko, RozaMaria). In European languages another lexeme is used - a person, le personne, die Person.

Besides, “лицо" (a face) may denote an important person, a significant society member: первые лица столиц (the first people of the capitals) (about big cities' mayors), первое лицо государства (the first person in a state), приказчикпервое лицо на заводе (a counterman - the first person in a factory) [7]. A definite collective assessment, connotation which contains this lexeme can be stated. The same connotation (importance, significance) is observed in the noun "голова": Наш староста - голова! (Our monitor is the head!) Хлеб - всему голова! (Bread is the head of all!)

It should be noted that such legal terms as “должностное лицо” (an official), “физическое лицо” (an individual), “доверенное лицо” (a trustee), “официальное лицо” (an authorized person),"юридическое лицо" (a legal entity) appear based on the meaning "a person as a society member". These terms are frequently used nowadays not only in the business but also in publicistic and spoken language: Согласно статье, сельскохозяйственный товаропроизводитель -физическое или юридическое лицо, осуществляющее производство аграрной продукции (According to the article a farm goods producer is an individual or a legal enitity carrying out the production of farm products) (“Agrarnyi zhurnal”, 2002.02.15); Сдам помещение в аренду физическому лицу (Lend premises to an individual) (from announcements).

Denoting a person with the word "лицо" (a face) is not only a national specific but also a very ancient component in the structure of a lexeme. [9]. During the 11-18th centuries the lexeme had seven lexical and semantic variants including "a creature, a human" and "honor, dignity". At present there are five meanings but the given above meaning has widened and has become to denote not only an individual but also a member of a society, as it has already been mentioned above. The meaning "honor, dignity" has remained in the phraseological units "не ударить лииом в грязь”, "потерять лиио" " (compared to the English to lose face and French perdre la face) or "сnасти лицо" - save one's face, sauver la face de qqn.

The words “лицо" (a face) and “лик" (a front, an image) are tightly connected with the basic national concept "Душа" (a soul). As is stated by a famous Russian linguist U.S. Stepanov "...if we see as it is the three parts of an individual's natural constitution, it follows that there are the parts of the natural constitution - spirit, soul, and body ....the personality or a person's hypostasis embraces all the parts of this natural constituency, expresses itself in an individual, exists in it and through it" [8]. Looking up in the dictionary of V. Dal [4], one can see that the first basic meaning is presented in much detail: "A face - in an elevated meaning a front, in a vulgar meaning mug - The front part of a human's head from the hair line to the ears and lower end of the cheekbone: forehead, eyes, nose, cheeks, lips, chin". But V. Dal doesn't restrict his definition by a detailed characteristic of face as part of the head, and provides very interesting information closely connected with the orthodox concepts: "A face of a person is the representative of higher spiritual gifts: forehead - heavenly love; eyes - reasoning, reasonable perception; ears - understanding and obedience; mouth thought and learning". Therefore V. Dal doesn't only point out the relevant signs of an object, but also reflects the world perception of his epoch stating the connection of the national and cultural concept "Душа" (a soul) with the word "лицо" (a face) [4].

\section{Results and Discussion}

This part includes the results obtained after data collection and data analysis. As a result of the research, the cross- 
cultural components, associated with the extralinguistic reality, were identified in the first group of words, such as " a two- or three-storey comfortable house outside the city for all-season usage(cottage)", "6 hundredth of a hectar, a garden, summer rest in the fresh air" and even "шашлык" (barbeque) - dacha, etc.

Analysis of the second group of words showed that in their structure there are linguocultural components associated with the Russian national perception of reality.In addition, this analysis helped to clarify and expand the semantic of the russian word "faсе" (лиио) in comparison with the definitions in the dictionaries. In its structure there are meanings honor, dignity, a person as an individual and a person as a member of society. Culturally significant moment is the connection of the word "face" and concept Soul.

Direct meanings of lexemes "голова" (a head), "лицо" (а face), "рука" (a hand) in explanatory dictionary definitions reflect a naïve consciousness of a native speaker: голова( head) - an upper part of a human's body; лицьо( a face) - a front part of a human's head; pука(a hand) - one of the two upper limbs of a human. The nominations of exactly these parts of a body may be used to denote a human as a whole. The derivative meanings realize implications established in the initial meanings and demonstrating the correlation "partwhole" through metonymy. It should be mentioned that the names for other parts of a body - "нога" (a leg), "шея" (a neck), “спина" (a back), 'затьллок” (a nape) etc. - are never used in the stated function.

The given analysis of the structure of such lexemes of the Russian language as "лицо" (a face), “голова" (a head), "рука" (a hand) from the point of view of plane of expression and plane of content manifests, on the one hand, the universal character of their denotata and, on the other hand, the differences in the significates dependent of the native speakers' world view.

\section{Conclusion}

The article was aimed to describe the lexical meanings of the language units reflecting the elements of the cultural codes. The meanings embody a certain worldview of the Russian native speakers. "Once again we emphasize an important point: psycholinguocultural approach is based on the assumption that the researcher's attention is focused first of all on the cultural signs in the language and their connotations in the ethnic society's consciousness, ... on the revelation of the common deep meanings that allow the representatives of different scientific branches speak about a people and its self-consciousness" [1].

Most often culture specific lexis, locoepistems, lacoons become an objective of linguocultural and regional geographical analysis as they vividly reveal ways of reality perception. The stated phenomena have already been registered and classified by linguists, culture specialists, and translators. It was interesting to give consideration to the common words belonging to the neutral, unmarked layer.

The carried out research of the words голова, лицо, рука, нога, дача, баня, кафе,, метро, коттедж drives us at the conclusion that the components of the semantic structure may reflect the culturally significant phenomena of the reality and provide interpretations the universal knowledge in accordance with the cultural settings of a certain society. In the given concrete case one can see that the unmarked equivalent lexis may contain information about the culture of the country of a studied language.

Linguocultural and regional geographical analysis based on the semantic analysis calls forth the building up of linguistic, cultural and communicative competence.

\section{References}

[1] Bubnova I. A. Yazyk I spetsifika nationalnogo miroponimania v Rossii XXI veka: sovremennie tendentsii issledovania. Sb. Yazyk. Soznanie. Kommunikatsia. M.: Maks-Press, 2016, № 23, s. 50.

[2] Bolshoy akademicheskiyi slovar' russkogo yazyka $\vee 30$ t. T. 9., s. 247-250; T. 13, s. 500-503 M- SPb, Nauka, 2009 g.

[3] Vereschyagin E. M., Kostomarov V. G. Yazyk I kultura. M.: Indrik, 2005, s. 77-78.

[4] Dal' V. I. Tolkovyi slovar' zivogo velikorusskogo jazyka. T. 2. M.: Drofa. Russkyi jazyk. Media,. 2011, s. 258.

[5] Klimenko G. V. Chasti tela cheloveka v aspekte lingvokulturologii. Sb. Russkiy yazyk I literature v prostranstve mirovoy kultury. Materialy ХШ Kongressa Mezhdunarodnoy assotsiatsii prepodavateley russkogo yazyka I literatuty. T. 6. SPb: MAPRIAL, 2015, s. 268.

[6] Ozhegov S. I.,. Shvedova N. U. Tolkovyi Slovar' russkogo yazyka. -Rossiyskaya Akademiya Nauk, Institut Russkogo yazyka im. Vinogradova. M.: Azbukovnik, 1999 g., s. 135.

[7] Slovar' russkogo yazyka v 4-h t., t. 2. M.: Russkiy yazyk, 1999 g., s. 191.

[8] Stepanov U.S. Konstanty. Slovar' russkoy kultury. M.: Akademicheskiy projekt, 2004, s. 741-742.

[9] Fasmer M. Etimologicheskyi Slovar' russkogo yazyka. -t. 2. M.: Progress, 1986, s. 506.

[10] Oxford Dictionary of English (second edition). Oxford University Press,. New York, 2003, p. 786.

[11] Webster 's New Dictionary of Synonyms. Merriam Company, Publishers, Springfield, Massachusettes, USA, 1973, p. 388389. 